Review

\title{
Typical Pediatric Brain Tumors Occurring in Adults-Differences in Management and Outcome
}

\author{
Ladina Greuter 1,*, Raphael Guzman 1,2,3 and Jehuda Soleman 1,2,3 \\ 1 Department of Neurosurgery, University Hospital of Basel, 4031 Basel, Switzerland; \\ raphael.guzman@usb.ch (R.G.); jehuda.soleman@usb.ch (J.S.) \\ 2 Division of Pediatric Neurosurgery, University Children's Hospital of Basel, 4031 Basel, Switzerland \\ 3 Faculty of Medicine, University of Basel, 4056 Basel, Switzerland \\ * Correspondence: ladina.greuter@usb.ch; Tel.: +41-61-328-5806
}

Citation: Greuter, L.; Guzman, R.; Soleman, J. Typical Pediatric Brain Tumors Occurring in

Adults-Differences in Management and Outcome. Biomedicines 2021, 9 ,

356. https://doi.org/10.3390/

biomedicines 9040356

Academic Editor: David

Cory Adamson

Received: 28 February 2021

Accepted: 25 March 2021

Published: 30 March 2021

Publisher's Note: MDPI stays neutral with regard to jurisdictional claims in published maps and institutional affiliations.

Copyright: (c) 2021 by the authors. Licensee MDPI, Basel, Switzerland. This article is an open access article distributed under the terms and conditions of the Creative Commons Attribution (CC BY) license (https:/ / creativecommons.org/licenses/by/ $4.0 /)$.

\begin{abstract}
Adult brain tumors mostly distinguish themselves from their pediatric counterparts. However, some typical pediatric brain tumors also occur in adults. The aim of this review is to describe the differences between classification, treatment, and outcome of medulloblastoma, pilocytic astrocytoma, and craniopharyngioma in adults and children. Medulloblastoma is a WHO IV posterior fossa tumor, divided into four different molecular subgroups, namely sonic hedgehog (SHH), wingless (WNT), Group 3, and Group 4. They show a different age-specific distribution, creating specific outcome patterns, with a 5-year overall survival of $25-83 \%$ in adults and $50-90 \%$ in children. Pilocytic astrocytoma, a WHO I tumor, mostly found in the supratentorial brain in adults, occurs in the cerebellum in children. Complete resection improves prognosis, and 5-year overall survival is around $85 \%$ in adults and $>90 \%$ in children. Craniopharyngioma typically occurs in the sellar compartment leading to endocrine or visual field deficits by invasion of the surrounding structures. Treatment aims for a gross total resection in adults, while in children, preservation of the hypothalamus is of paramount importance to ensure endocrine development during puberty. Five-year overall survival is approximately $90 \%$. Most treatment regimens for these tumors stem from pediatric trials and are translated to adults. Treatment is warranted in an interdisciplinary setting specialized in pediatric and adult brain tumors.
\end{abstract}

Keywords: adult brain tumors; pediatric brain tumors; medulloblastoma; pilocytic astrocytoma; craniopharyngioma

\section{Introduction}

In children, brain tumors are the most frequent solid cancer observed, with an incidence reported of 5.7 per 100,000 children, while in adults, the incidence is much higher with 29.9 per 100,000 persons [1]. Pediatric and adult brain tumors do not only differ in their incidence but also in histology, molecular pathology, location, and outcome [1]. However, some typical pediatric brain tumors, at times, occur also in adults. Of these, germinomas, non-germinomatous germ cell tumors or pineal region tumors show comparable behavior or occur equally often in children or adults [2-7]. On the contrary, medulloblastoma, pilocytic astrocytoma, and craniopharyngioma differ essentially in their incidence, location, histology and molecular pathology, treatment strategies, or outcomes between the two age groups. It is to be assumed that the knowledge of how to deal with these pediatric brain tumors might be limited within the adult word since their incidence is lower in the adult population. The aim of this review is to give an overview of these three classical pediatric brain tumors and emphasize on their incidence, behavior, classifications, treatment strategies, and outcome in the adult population, while comparing to their pediatric counterparts. 


\section{Medulloblastoma}

\subsection{Incidence and Classification}

Medulloblastoma (MB) is the most common malignant brain tumor in children, with an incidence of 5-6 cases per million children. However, in adults, medulloblastoma is a very rare tumor, accounting for only 0.6 cases per million persons. MB can be associated with cancer predisposition syndromes, such as Gorlin, Turcot, or Li Fraumeni syndrome [8]. The biology of MB with different molecular and genetic subgroups varies across the different age groups, and creates subgroup- and age-specific patterns with different outcome $[2,7,9]$. Historically, MB were divided according to the Chang classification for local tumor invasion (T stage) and metastasis (M-stage) [10]. In adults, prognostic association of T-stage and outcome was found, while in children, no such evidence exists [2,11,12].

According to the WHO brain tumor classification, MB are by definition WHO grade IV tumors regardless of their subtype [13]. Histologically medulloblastomas are divided into three main subtypes: classic, nodular/desmoplastic, or large cell/anaplastic [13]. Additionally, extensive nodular histology, exclusively existing in infants, and not otherwise specified (NOS) MB were added to the WHO classification [13-15]. In the previous WHO guidelines large cell and anaplastic histology were classified separately, however, large cell medulloblastomas mostly also show anaplastic features, which is why these types were grouped together $[13,15,16]$. Nodular/desmoplastic histology was described to occur more frequently in adults and is associated with a lower risk classification than classic or anaplastic types in both age groups [17]. Additionally, with the development of genetic and molecular analysis, new subgroups have been defined in the last decade. According to the consensus conference in 2016, medulloblastomas are divided into three main subgroups according to their genetic and molecular changes: wingless-type (WNT), sonic hedgehog (SHH), and non-WNT/non-SHH with Group 3, and Group 4 [13,18]. Recently, new subclassifications for Group 3 and Group 4 medulloblastomas were added based on DNA methylation profiling [19]. Several additional prognostic factors based on gene expression were identified, such as MYC in Group $3 \mathrm{MB}$ and $M Y C N$ amplification in Group $4 \mathrm{MB}$ (poor prognosis), and TP53 mutation (poor prognosis) in adult SHH-MB [2,7,20].

SHH-MB TP53 wild-type is the most common subgroup found in adults [20,21]. It shows a male predominance (2:1), and accounts for around $60 \%$ of adult MBs and is significantly associated with nodular/desmoplastic histology [11,21-24]. WNT-MB occurs in approximately 10-15\% of adults and displays classic histology in 95\%. WNT-MB shows the best overall survival, however, in adults a more aggressive behavior is observed than in children $[21,23,25]$. The remaining $25 \%$ of adult $\mathrm{MB}$ are represented by non-SHH non-WNT MB, mostly belonging to Group 4-MB. In adults, a third of Group 4-MB show anaplastic histology and metastatic disease, both factors which are associated with a poor prognosis $[23,25,26]$. Group 3-MB are predominantly found in infants and were only later on described in adults, in which they are a rare occurrence $[20,22,23,25]$. An overview of the different subgroups and their differences in adults and children is shown in Table 1.

Table 1. Characteristics for the molecular subgroups of adult and pediatric medulloblastoma, based on data from the following references $[2,7-9,11,13,18,21-25,27-30]$. Abbreviations: CPA = cerebellopontine angle, $\mathrm{SHH}=$ sonic hedgehog, $\mathrm{WNT}=$ wingless, $\mathrm{OS}=$ overall survival.

\begin{tabular}{ccccccccc}
\hline & \multicolumn{1}{c}{ Adults } & \multicolumn{3}{c}{ Children } \\
\hline Subgroup & SHH & WNT & Group 3 & Group 4 & SHH & WNT & Group 3 & Group 4 \\
\hline \% of cases & $60-65 \%$ & $10-15 \%$ & $5 \%$ & $20 \%$ & $20-25 \%$ & $10-15 \%$ & $20-25 \%$ & $40 \%$ \\
\hline $\begin{array}{c}\text { Gender } \\
\text { Ratio (m:f) }\end{array}$ & $2: 1$ & $1: 1$ & $2: 1$ & $4: 1$ & $2: 1$ & $1: 1$ & $2: 1$ & $1: 1$ \\
\hline Lecation & $\begin{array}{c}\text { Sphellar } \\
\text { hemi- } \\
\text { CPA }\end{array}$ & $\begin{array}{c}\text { Cerebellar } \\
\text { hemi- } \\
\text { sphere/ } \\
\text { CPA }\end{array}$ & $\begin{array}{c}\text { Midline, } \\
\text { 4th } \\
\text { ventricle }\end{array}$ & $\begin{array}{c}\text { Midline, } \\
\text { 4th } \\
\text { ventricle }\end{array}$ & $\begin{array}{c}\text { Cerebellar } \\
\text { hemi- } \\
\text { sphere }\end{array}$ & $\begin{array}{c}\text { Cerebellar } \\
\text { hemi- } \\
\text { sphere }\end{array}$ & $\begin{array}{c}\text { Midline, } \\
4 \text { th } \\
\text { ventricle }\end{array}$ & $\begin{array}{c}\text { Midline, } \\
4 \text { th } \\
\text { ventricle }\end{array}$ \\
\hline
\end{tabular}


Table 1. Cont.

\begin{tabular}{|c|c|c|c|c|c|c|c|c|}
\hline \multirow[b]{2}{*}{ Subgroup } & \multicolumn{4}{|c|}{ Adults } & \multicolumn{4}{|c|}{ Children } \\
\hline & SHH & WNT & Group 3 & Group 4 & SHH & WNT & Group 3 & Group 4 \\
\hline Histology & $\begin{array}{c}\text { Nodular- } \\
\text { desmoplastic }\end{array}$ & Classic & Classic & $\begin{array}{c}\text { Classic/ } \\
\text { Anaplastic }\end{array}$ & $\begin{array}{c}\text { Classic/ } \\
\text { Nodular- } \\
\text { desmoplas- } \\
\text { tic/ } \\
\text { Anaplastic }\end{array}$ & Classic & $\begin{array}{c}\text { Classic/ } \\
\text { Anaplastic }\end{array}$ & $\begin{array}{l}\text { Classic/ } \\
\text { Anaplastic }\end{array}$ \\
\hline $\begin{array}{l}\text { Metastasis } \\
(\%)\end{array}$ & $<10$, local & $<10$, local & $\begin{array}{r}10-15 \\
\text { distant }\end{array}$ & 20, distant & $\begin{array}{l}\text { 10-15, } \\
\text { Local }\end{array}$ & $<10$, Local & 40, Distant & 35, Distant \\
\hline $\begin{array}{l}\text { Molecular/C } \\
\text { alterations }\end{array}$ & $\begin{array}{l}\text { entib3 (poor } \\
\text { prognosis) }\end{array}$ & TP53 & MYC N * & MYC * & $\begin{array}{l}\text { TP53 (poor } \\
\text { prognosis) } \\
\text { MYC N }\end{array}$ & - & MYC N & MYC \\
\hline Prognosis & $\begin{array}{l}\text { Intermediate, } \\
\text { Poor with } \\
\text { TP53 }\end{array}$ & Good & Poor & Intermediate & $\begin{array}{l}\text { Intermediate, } \\
\text { Poor with } \\
\text { TP53, } \\
\text { Infants } \\
\text { better }\end{array}$ & Excellent & Poor & Intermediate \\
\hline $\begin{array}{c}\text { 5-year OS } \\
(\%)\end{array}$ & $\begin{array}{c}\text { 81\% } \\
\text { TP53: } 41 \%\end{array}$ & $82 \%$ & $25 \%$ & $39 \%$ & $\begin{array}{c}\text { 75-90\%, } \\
\text { TP53: } \\
40-50 \%\end{array}$ & $>90 \%$ & $\begin{array}{c}55 \% \\
\text { MYC N: } \\
<50 \%\end{array}$ & $75-90 \%$ \\
\hline
\end{tabular}

${ }^{*}$ rare in adults.

\subsection{Clinical Presentation and Diagnostic Tools}

In adults, $\mathrm{MB}$ are mostly localized in the cerebellar hemisphere (SHH-MB) resulting in gait ataxia (68\%) and/or vestibular syndromes (41\%), while in children, MB mostly occurs in the midline and causes hydrocephalus due to an obstruction of the 4 th ventricle (Figure 1).
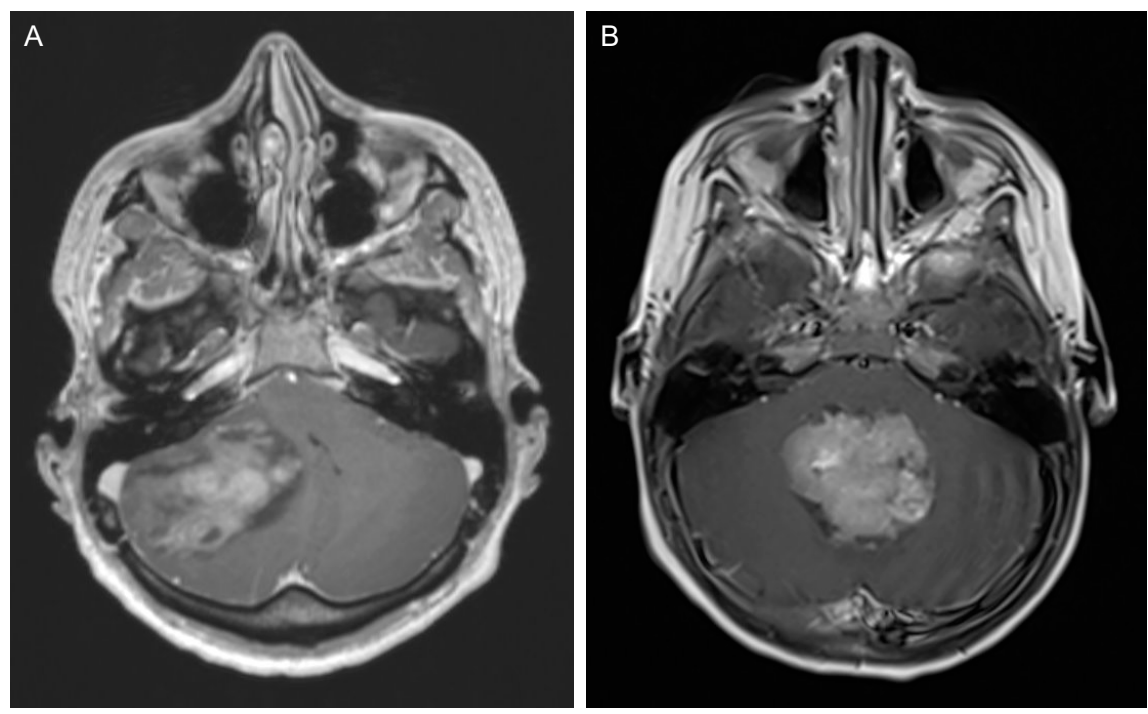

Figure 1. (A) 27-year-old male, presenting with headache and ataxia. Axial MRI shows a lateral cerebellar mass with concomitant hydrocephalus. He recovered well after surgical tumor resection. Histopathological analysis diagnosed an SHH-MB, classic histology, TP53 wild-type. He received CSI and chemotherapy according to the Packer regiment [31]. (B) 3-year-old female, presenting with vomiting and unsteady gait. Axial MRI shows a lesion in the 4th ventricle with obstruction and hydrocephalus. Preoperative CSF diversion was installed and after complete resection, the patient required a ventriculo-peritoneal shunt and recovered well. Histopathological analysis showed a Group 3 MB, MYC amplification negative, anaplastic histology. Further work-up showed a spinal lesion suggestive of metastasis (not shown). She received chemotherapy according to the HIT-study regiment [32]. 
Due to the mass effect and elevated intracranial pressure in the posterior fossa, 80-90\% of adults and children suffer from headaches and vomiting [33-35]. Most symptoms have been present for a longer period of time (approximately 2 months) at the time of diagnosis, but especially in children, who often present with unspecific symptoms and psychomotor regression at first, the delay between symptom onset and diagnosis can reach up to several months [33,34,36].

Magnetic resonance imaging (MRI) is the method of choice for diagnosis. MB presents as iso- to hypointense mass on T1 and hypo- to hyperintense on T2 images. It enhances with contrast and shows an increased signal on diffusion-weighted imaging series (DWI) [2,37]. Adult MB shows a more irregular contrast enhancement compared to pediatric MB, which allows for a correlation between imaging and molecular subtype [37]. Similar to the pediatric population, also in adults, a complete neural axis, including spinal axis, MRI imaging with contrast is recommended [2,38].

\subsection{Management and Outcome}

In both children and adults, surgery is the primary therapy. Depending on the individual case a temporary CSF diversion (extraventricular drain [EVD] or endoscopic third ventriculostomy [ETV]) needs to be performed primarily [2]. Permanent CSF diversion with a ventriculo-peritoneal shunt is indicated in $20 \%$ of all medulloblastoma patients, but is significantly lower in patients suffering from WNT-MB [39]. In general, young age ( $<2$ years) is a risk for developing shunt dependency after surgery of a posterior fossa lesion and children (20-40\%) require permanent shunting more often than adults (7-21\%) [40-42]. The primary aim of surgery is gross total resection, however, since MB can invade the floor of the 4 th ventricle, a maximal safe resection is key for a good outcome. Since MB in adults is more often localized to the cerebellar hemisphere (especially SHH-MB) a gross total resection is achieved more often. A remaining tumor volume of $<1.5 \mathrm{~cm}^{3}$ should be aimed for if feasible, as it is of positive prognostic value in children [43]. The surgical approach chosen is similar in adults and children and depends on the individual tumor location. In children, however, special care should be taken to spare the vermis. Children tend to develop posterior fossa syndrome, a combination of mutism, cranial nerve deficits, and emotional lability, after manipulation of the vermis (referred to as "posterior fossa syndrome"), while this phenomenon is less often observed in adults [44,45]. To avoid extensive traction of the cerebellum, a telovelar approach is recommended for midline tumors, which can either be done in a prone, park-bench, or sitting position, depending on the surgeon's preference [2].

Postoperative outcomes mostly depend on the molecular subgroup of MB, as mentioned above. However, regardless of the subgroup, to this date, craniospinal irradiation (CSI) with a boost to the posterior fossa is recommended for all patients above the age of 3 years. Deescalating therapies depending on molecular subtypes, especially for more favorable subtypes like WNT- and SHH-MB, are being studied. Most studies investigating CSI in medulloblastoma, were carried out in the pediatric population, while their results are extrapolated to the adult population. CSI was shown to significantly increase progression-free survival (PFS) and overall survival (OS) in MB and should be commenced within 6 weeks after surgery $[2,9,12,46]$.

Additional to CSI, chemotherapy is recommended for MB irrespective of the tumor subgroup or the patient's age [27]. Young children receive a combination of cyclophosphamide, vincristine, carboplatin, etoposide and intrathecal methotrexate, according to the HIT 2000 regiment [28]. Chemotherapy regimens for adults are adapted from pediatric trials, and are based on a regiment (Packer regiment) with vincristine, followed by lomustine (CCNU), and cisplatin $[28,31,47]$. Adolescents and adults, however, show a lower tolerance and higher toxicity to chemotherapy compared to children, and individual adaptions to the standard protocol might be required [2,29]. In adults, a protocol by Franceshi et al. using cisplatin or carboplatin plus etoposide, showed an improvement of the PFS at 15 years in patients treated with radiotherapy and chemotherapy (PFS 82.3\% $\pm 8.0 \%$ ) compared to pa- 
tients treated with radiotherapy alone (PFS 38.5\% $\pm 13.0 \%, p=0.05$ ) [27]. Adult MB shows a tendency towards late recurrences ( $>5$ years after initial diagnosis), hence, a long-term follow-up is recommended $[11,33]$. In the treatment arm of the study by Franceshi et al., OS for adult MB at 10 years is reported at $89 \%[11,27]$. In general, adults have a worse OS compared to children with $\mathrm{MB}$, but the molecular subtype is of paramount importance in assessing the individual prognosis in children and adults [18,27], (Tables 1 and 2).

Table 2. Overall characteristics for adult and pediatric medulloblastoma based on the following references $[8,11,12,27,29,33-$ 35,40-42,44,45] Abbreviations: CSI = craniospinal irradiation.

\begin{tabular}{ccc}
\hline Characteristics & Adults & Children \\
\hline Incidence per $\mathbf{1 0 ^ { \mathbf { 6 } } \text { persons }}$ & 0.6 & $5-6$ \\
\hline Location (most common) & Cerebellar hemisphere & Midline, 4 th ventricle \\
\hline Presenting Symptom & $\begin{array}{c}60 \% \text { gait ataxia, } \\
>80 \% \text { vestibular syndrome, } \\
\text { Associated Syndromes }\end{array}$ & $>80 \%$ vomiting, hydrocephalus \\
\hline Molecular alterations & Depending on subtype & Li-Fraumeni, Gorlin, Turcot \\
\hline Metastasis & Depending on subtype & Depending on subtype \\
\hline Primary Treatment & Surgery & Depending on subtype \\
\hline Additional Therapy & Chemotherapy (Packer regiment), CSI & Chemotherapy (HIT 2000 regiment), CSI \\
$(>3$ years)
\end{tabular}

Novel targeted therapies on a molecular level, might potentially change the treatment regimens and prognosis of medulloblastoma in children and adults $[48,49]$. SHH-MB can be targeted with Smoothened (SMO) inhibitors, such as sonidegib and vismodegib [30]. So far only phase I and II trials in recurrent MB are available [30]. A study with sonidegib in children and adults showed a tumor response in SHH-activated medulloblastomas, however, in children the drug was discontinued early due to its inhibitory effect on skeletal growth plates [50]. Similar results were described for vismodegib [51]. However, it has to be considered that SHH-MB are rare in children, and these drugs might have a limited use in this age group, while they could hold promising results in adults [30].

\section{Pilocytic Astrocytoma}

\subsection{Incidence and Classification}

Pilocytic astrocytoma (PA, also known as juvenile pilocytic astrocytoma) is one of the most common brain tumor found in children, comprising $15 \%$ of all pediatric brain tumors [52]. In adults however, PA is less frequent with an incidence of 0.1 per 100,000 persons compared to 0.8 per 100,000 children [5,6]. Children suffering from neurofibromatosis type 1 (NF-1) and tuberous sclerosis (TS), two cancer-predisposition syndromes, show a higher rate of low-grade gliomas. Children with TS develop subependymal giant cell astrocytoma, a specific subtype of astrocytoma, while children with NF-1 show a predilection for optic gliomas, a subtype of PA [6,52], while in adulthood patients with NF-1 tend to develop high-grade gliomas [53,54]. In general, PA can occur anywhere in the central nervous system, but the classical childhood PA occurs in the cerebellum, while in adults, it is found in the supratentorial compartment. Highly eloquent localization in the brainstem is observed in around $10-20 \%$ in children and in around $5 \%$ in adults, while spinal manifestation occurs in approximately $2-5 \%$ in both age groups [55-57]. PA is by 
definition a WHO Grade I tumor [13]. It differs from other low-grade gliomas (LGG), as it is not a precursor of diffuse gliomas, which occur in both age groups and tend to undergo malignant transformation, especially in adults $[13,58,59]$. Histologically, PA shows areas of compact astrocytes and Rosenthal fibers and areas of loosely textured cells. Proliferation indices like $\mathrm{Ki}-67$ are around $4 \%$ and anaplasia is rarely observed in PA but occurs more frequently in NF-1 patients or older patients [60-62]. Histopathological analyses have shown that an activation of the PI3K/AKT pathway might increase the aggressiveness of PA, leading to higher recurrence rates and lower overall survival [61,62]. MGMT promoter methylation was also discovered in over half of anaplastic PA but not in PA in general, however, no association of MGMT promoter methylation with outcome was shown so far [62]. Molecular analysis detect a fusion or mutation of the BRAF gene in up to $70 \%$ of childhood PA, which might activate oncogenic pathways, and could have prognostic implications [63-65]. However, BRAF fusion was only found in $20 \%$ in adult PA, indicating a decrease of $B R A F$ fusion with increasing age [66].

\subsection{Clinical Presentation}

Children and adults mostly present with headache, nausea, and vomiting, due to elevated intracranial pressure. Additional symptoms like motor deficits or ataxia are dependent on the individual tumor location. Despite hydrocephalus present at the time of diagnosis, only a few patients need preoperative CSF diversion. Especially in children, symptoms were retrospectively present for several months already, until the definitive diagnosis was made [36,67].

Initial diagnosis is mostly made by MRI, which in the posterior fossa usually presents as a cyst with a mural tumor nodule. The solid nodule is T1-hypointense and T2-hyperintense compared to the brain tissue, and the cyst wall mostly enhances with contrast [68]. In the spinal cord, PA also presents as a cystic and nodular tumor, which enhances with contrast and mostly shows an eccentric growth pattern [69].

\subsection{Management and Outcome}

The primary therapy of PA is gross total resection (GTR) of the tumor, which leads to excellent PFS and OS. However, for deeply or eloquently seated lesions (brain stem, optic tract), usually, only a partial resection is feasible, and in most cases the cyst wall is mostly benign and can be left intact [70,71]. These patients were shown to have a higher risk for mortality compared to patients with cerebral or cerebellar tumor location $[6,56,72]$. So far, GTR is the only treatment in adults, which showed a benefit in survival [6,73]. Radiotherapy in adult and childhood PA is controversially discussed [6,56]. No interventional trials for radiotherapy in PA exist. In current practice, most patients receiving radiotherapy have either a deep-seated lesion, recurrence, or discordant histopathology, which influences the outcome of observational studies towards a shorter PFS in patients receiving radiotherapy $[6,56,74]$. Radiotherapy is avoided in very young children or children suffering from NF-1, due to their increased risk of irradiation-induced cell damage and the potential of malignant transformation of the tumor [52,59]. Chemotherapy is mostly administered at recurrence. In a retrospective cohort study, only $13 \%$ of adults and children received radioor chemotherapy postoperatively, while the administration of chemotherapy increases for patients with optic or brainstem PA or only partial tumor removal [75]. Chemotherapy in adults consists either of temozolomide or a regimen of carboplatin, etoposide, and vincristine [56], while in children, cisplatin, vincristine, or vinblastine are administered [76]. Recently, with the development of molecular analysis and pathway recognition, novel targeted therapies with MEK-inhibitors are being tested, showing promising results. However, as $B R A F$ mutations are rare in adults, these novel targeted therapies remain reserved mainly for childhood PA [77,78].

In general, adults show a more aggressive behavior of PA than children, with recurrence rates of over $30 \%$. Five-year overall survival for adult PA is estimated at $83-87 \%$, 
while for pediatric PA a 5-year overall survival of $95 \%$ can be reached [6,55-57]. An overview of the characteristics of adult and childhood PA is shown in Table 3.

Table 3. Characteristics for adult and pediatric pilocytic astrocytoma, based on data from the following references $[5,6,13,54-$ 58,64-66,75]. Abbreviations: OS = overall survival, NF = neurofibromatosis, GTR = gross total resection, $\mathrm{STR}=$ subtotal resection, $\mathrm{MEK}$ inhibitor $=$ mitogen-activated protein kinase.

\begin{tabular}{ccc}
\hline Characteristics & Adults & Children \\
\hline Location (most common) & $\begin{array}{c}\text { supratentorial }(35-45 \%), \text { cerebellar } \\
(35-40 \%), \text { brain stem, optic pathway } \\
(5-10 \%), \text { spinal }(2-5 \%)\end{array}$ & $\begin{array}{c}\text { cerebellar }(70 \%), \text { brain stem, optic } \\
\text { pathway }(10-20 \%), \text { spinal }(2-5 \%)\end{array}$ \\
\hline Associated Syndromes & - & NF-1, Tuberous Sclerosis Complex \\
\hline Molecular alterations & BRAF: 20\% & BRAF: 70\% \\
\hline Primary Treatment & Surgery & Surgery \\
\hline Additional Therapy & $\begin{array}{c}\text { Chemotherapy (temozolomide, } \\
\text { carboplatin, etoposide), Radiation for } \\
\text { deep-seated lesions, recurrence }\end{array}$ & $\begin{array}{c}\text { Chemotherapy (cisplatin, vincristine, or } \\
\text { vinblastine), Radiation }(>3 \text { years) for } \\
\text { deep-seated lesions or recurrence, MEK } \\
\text { inhibitor for BRAF mutation }\end{array}$ \\
\hline Prognostic Factors & GTR (good) & Cerebellar location, GTR (good) \\
\hline 5-year OS (\%) & $83-87 \%$ & $>90 \%$
\end{tabular}

\section{Craniopharyngioma}

\subsection{Incidence and Classification}

Craniopharyngiomas show a bimodal age distribution with a peak between $5-14$ years and a second peak in adults between $50-70$ years. The overall incidence is $0.13-0.18$ per 100,000 persons in adults and children, while it seems that the incidence is similar in both children and adults $[79,80]$. Craniopharyngiomas constitute around 4-9\% of pediatric brain tumors and $2-5 \%$ of adult intracranial tumors [81,82]. According to the WHO classification of tumors, craniopharyngiomas are regarded as histopathologically benign lesions (WHO I) [13]. The two major histopathological subtypes of craniopharyngioma are adamantinomatous (ACP) and papillary (PCP) [83]. The first can occur in any age group, but is predominantly found in children, while the latter is only found in adults $[82,84,85]$. ACP mostly presents with macroscopic cysts, filled with cholesterol-containing fluid, and calcifications, while PCP present as solid tumors. Both types differ concerning their oncogenic genetic alterations, with changes in the Wnt/B-catenin pathway due to a CTNNB1 mutation for ACP and a BRAF mutation for PCP [85-87]. No differences in methylation profiles between adult and pediatric ACP were described [88].

\subsection{Clinical Presentation}

Craniopharyngiomas cause symptoms due to their intrasellar location and suprasellar growth, resulting in compression or invasion of the surrounding structures (optic nerve/chiasm, pituitary, hypothalamus, 3rd ventricle). The grade of hypothalamic involvement can be classified on preoperative MRI according to Puget et al. in Grade (1) no hypothalamic involvement, Grade (2) hypothalamic displacement, and Grade (3) hypothalamic invasion [89]. Despite similar tumor location, main clinical symptoms differ between children and adults. In adults, the main symptom at diagnosis are visual field deficits, while these are detected later in children [90]. Bitemporal hemianopia due to chiasmal compression is the most common visual field deficit and is found in around $60 \%$ of all patients with CP. Typical endocrinological deficits due to compression of the pituitary stalk occur in over $60 \%$ of children but only in around $30 \%$ of adults [90]. Endocrine deficits in children often manifest with a short stature or delayed puberty [82]. Froehlich's Syndrome is a combination of hypogonadism and obesity due to a hypothalamic pituitary pathway failure observed only in childhood craniopharyngioma [87,89]. Adults mostly 
present with more subtle hormonal deficits, which might be only found in laboratory examinations $[82,91,92]$.

\subsection{Treatment Strategies and Outcome}

In both age groups, the main treatment consists of surgical resection. The planned surgical resection depends on the anatomical extension of the tumor, but in adults generally the aim is for a GTR or near total resection (NTR, $>90 \%$ of tumor volume), while cyst drainage alone is rarely observed [90]. However, in children, the optimal treatment strategy is more controversially discussed $[3,93]$. It should mainly aim for a relief of symptoms ensuring local tumor control, while preserving a high quality of life, and not ultimately aim for a complete resection risking endocrine deficits caused by hypothalamic injury [89]. Postoperative hypothalamic injury can be classified in the same fashion as preoperative invasion [89]. Especially in children with a Puget grade 2 hypothalamic invasion, the goal of surgery should be tumor reduction or cyst drainage and not GTR [89]. Children with hypothalamic impairment, have a very high rate of hyperphagia, obesity, neurocognitive deficits, and lower quality of life, and therefore one of the main goals during surgery in children is preservation of the hypothalamus [89,93-95]. The preservation of the hypothalamus and also pituitary stalk during surgery reduces the rate of postoperative diabetes insipidus, but could cause a higher risk for tumor recurrence in both children and adults [82,96-98]. For these reasons, more and more pediatric neurosurgeons consider a tumor cyst fenestration and aspiration with tumor biopsy (endoscopically or stereotactically) as the primary treatment since it improves the symptoms and causes significantly lower overall morbidity compared to GTR $[3,99,100]$. After cyst fenestration, a drain can be left in-situ and connected to an Ommaya reservoir, which allows for repeated cyst aspirations (Figure 2).
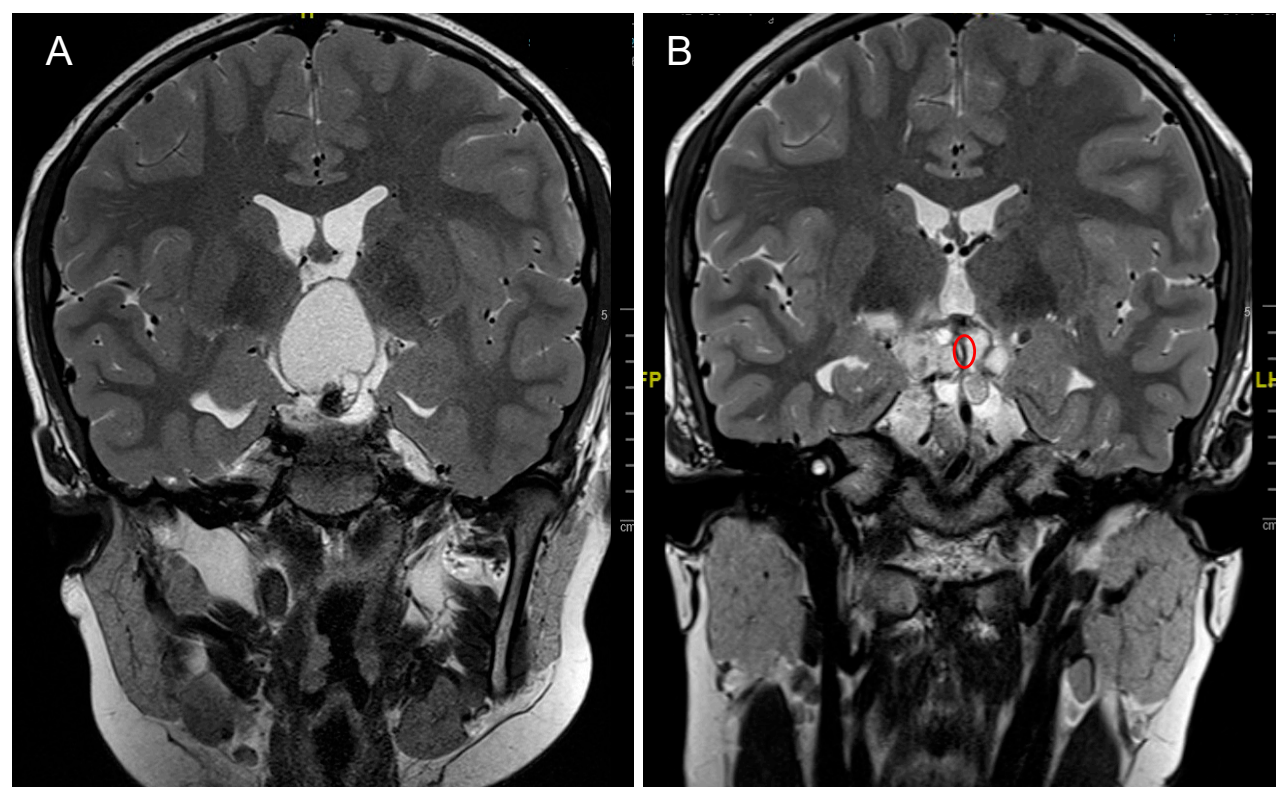

Figure 2. 12-year-old male, presenting with growth delay and obesity due to endocrine deficits caused by an adamantinomatous craniopharyngioma, Puget 2. (A) Preoperative coronal image showing a space-occupying cyst of the CP causing hydrocephalus. (B) Postoperative coronal image showing drained cyst and the tip of the inserted drain (red circle). The patient was then treated with proton beam therapy as an adjuvant treatment to surgery.

If the procedure is done endoscopically, STR can be achieved as well, leading to a reduction of the tumor volume as preparation for the proton beam therapy, which is administered as an adjacent measurement to surgery [101]. Also, in adults, endocrine deficits are often observed with radical resections of invasive tumors affecting the hypothalamus and pituitary stalk, however, this does not result in any developmental impairments as observed in children, but rather in endocrine dysfunctions, which are then treated with hor- 
monal replacement medication $[85,90,93]$. For surgery in adults, either an open transcranial or transsphenoidal approach can be chosen (Figure 3).
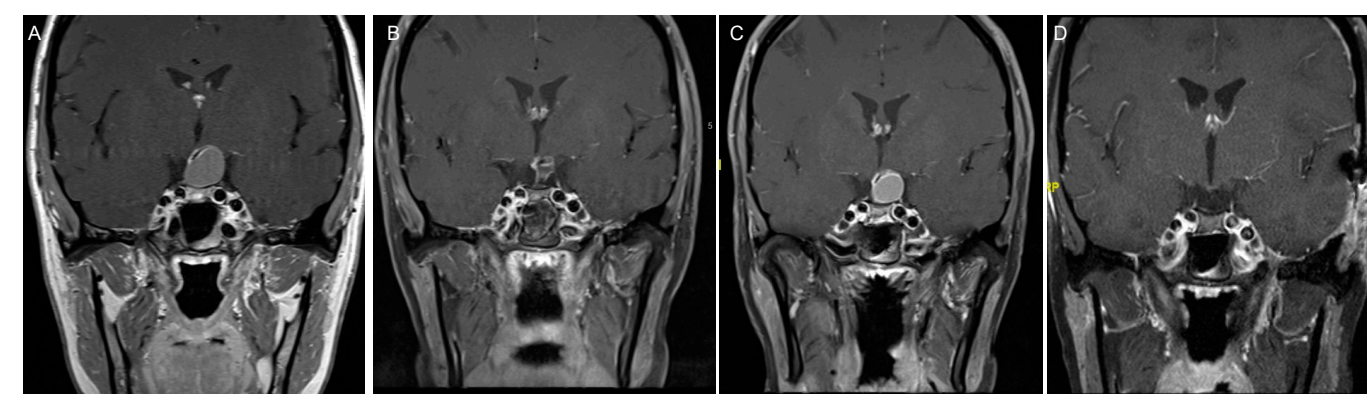

Figure 3. 27-year-old female patient, presenting with amenorrhea and disturbed peripheral color vision. (A) MRI for further analysis showed a cystic tumor with compression of the pituitary gland. (B) She first underwent transsphenoidal cyst fenestration and partial resection, which she recovered from well with full recovery from her visual deficits. Histopathology diagnosed an adamantinomatous CP. (C) Within 6 months, a progression of the cyst was observed, and she again developed visual field deficits and disturbed color vision. (D) She then underwent pterional craniotomy for complete tumor removal and additionally received proton beam therapy as adjuvant therapy. Her visual field deficits improved over time, while her endocrine deficits persisted, requiring hormonal substitution. Nowadays, the pediatric approach with neuroendoscopic cyst fenestration followed by proton beam therapy could have been applied for this case, while craniotomy is the more traditional approach.

However, some authors show in adults with cystic craniopharyngiomas similar surgical strategies as in children with cyst fenestration, tumor reduction, Ommaya reservoir, and radiation [102,103]. In CPs with a large lateral or cranial extension, transsphenoidal approaches might be limited due to the carotid arteries or suprachiasmatic location [104]. If a transsphenoidal approach is chosen in children, one has to consider, that the pneumatization of the sphenoid sinus only starts after the age of 3 years and is not fully developed until the age of 12-14 years, limiting these approaches in young children [105]. A literature review by Komotar et al. showed a significantly higher extent of resection with either microsurgical or endoscopic transsphenoidal approach compared to open transcranial surgery, promoting transsphenoidal approaches [106]. STR has a recurrence rate of up to $100 \%$, however, even if GTR is assumed, recurrences can be observed in up to $20 \%$ of the cases $[3,84,102,107]$. In addition, GTR was not shown to correlate significantly with OS in adults. This promotes the strategy of a planned partial resection, especially in elderly patients, and patients with a known hypothalamic involvement, to reduce endocrine deficits postoperatively [90]. In summary, for the adult population the surgical strategy for non-cystic $\mathrm{CP}$ is transsphenoidal resection whenever possible, while GTR should be the goal of surgery. For cystic $\mathrm{CP}$, traditionally, an open transcranial or transsphenoidal approach was the treatment of choice. To date, more and more authors adopt the surgical strategy used in the pediatric population of endoscopic cyst fenestration, tumor reduction and adjuvant proton beam therapy, since the morbidity of surgery is significantly lower. Further studies in adults are still needed to show that this treatment strategy concerning PFS, and OS is similar in adult as in the pediatric population.

Postoperative radiotherapy as fractionated radiotherapy, radiosurgery, or proton beam therapy is described for local tumor control in adults, however, is mostly restricted to smaller tumors or residual tumor after surgery. Local tumor control with fractionated radiotherapy is best achieved with doses around 54-55 Gy, because with increased doses an elevated risk for endocrine side effects is observed [108]. In children, proton beam therapy showed a lower rate of radiation to the surrounding structures, especially to the optic apparatus and hypothalamus, compared to conventional radiotherapy and achieves a good local tumor control $[103,109,110]$. Hence, it is often used in combination with tumor reduction surgery or cyst drainage to ensure local tumor control, without risking hypothalamic injury by extensive surgery [101]. No instillation of chemotherapy or similar 
substances (bleomycin, radioisotopes, interferon alpha) has been described in adults, and these experiences are solely based on pediatric populations with mixed results $[93,99,108]$. In PCP, therapy targeting the BRAF mutation with Dabrafenib or Vemurafenib showed a good radiographic response and tumor control in a few cases [111]. In ACP, targeted therapies with MEK inhibitors could have a certain therapeutic potential, however, reports are scarce $[112,113]$. Further trials with targeted therapies in $\mathrm{CP}$ are needed in the future.

In general, $\mathrm{CP}$ has an excellent 5-year survival rate of $90 \%$ in both pediatric and adult population $[84,90,102]$. An overview of the characteristics of pediatric and adult $\mathrm{CP}$ is shown in Table 4.

Table 4. Characteristics for adult and pediatric craniopharyngioma, based on data from the following references [76-81,8386,91,98,99,106-108] Abbreviations: CP = Craniopharyngioma, OS = overall survival.

\begin{tabular}{ccc}
\hline Characteristics & Adults & Children \\
\hline Age Distribution (years) & $50-70$ & $5-14$ \\
\hline Frequency (\%) & $2-5$ & $4-9$ \\
\hline Histology & Adamantinomatous \& Papillary CP & Adamantinomatous CP \\
\hline Molecular alterations & CTNNB1 (aCP), BRAF (pCP) & CTNNB1 \\
\hline Presenting Symptom & Visual field deficit & Endocrine disturbances \\
\hline Endocrine Deficits at Presentation (\%) & $30 \%$ & $60 \%$ \\
\hline Primary Treatment & GTR if possible, radiotherapy, BRAF \\
targeted therapy & $\begin{array}{c}\text { Tumor reduction /cyst drainage, proton } \\
\text { beam therapy, local } \\
\text { chemotherapy(controversial) }\end{array}$ \\
\hline Endocrine Postoperative Complications & $\begin{array}{c}70 \% \text { diabetes insipidus, 15\% growth } \\
\text { hormone deficiency }\end{array}$ & $\begin{array}{c}75 \% \text { growth hormone deficiency, 20\% } \\
\text { diabetes insipidus }\end{array}$ \\
\hline Visual Field Complications & $\begin{array}{c}7-14 \% \text { visual field deficits, good } \\
\text { postoperative recovery in 60\% }\end{array}$ & $\begin{array}{c}8-20 \% \text { visual field deficits, good } \\
\text { postoperative recovery in 50\% }\end{array}$ \\
\hline 5-year OS (\%) & $\sim 90 \%$ & $\sim 90 \%$
\end{tabular}

\section{Conclusions}

The same tumor entities, namely medulloblastoma, pilocytic astrocytoma and craniopharyngioma, show differences in their incidence, histopathological and molecular features, treatment, and outcome between children and adults. This requires individual management strategies for the different age groups.

In $\mathrm{MB}$ the distribution of the different subtypes varies among the age groups and has implication on the individual prognosis. However, surgery remains the primary therapy in most cases, followed by radio- and chemotherapy.

In adults, PA is mainly a supratentorial tumor, while in children it is a commonly found infratentorial. GTR is the primary therapy for PA in both age groups and correlates with a benefit in survival. Radio-or chemotherapy is only administered in around $10 \%$ of all cases and is reserved for recurrent tumors.

$\mathrm{CP}$ with its intra- and suprasellar location, mostly causes symptoms due to compression and invasion of the surrounding structures. In adults the presenting symptoms are bitemporal hemianopia, while children mostly present with endocrine deficits. Surgery with the aim to reduce the mass effect and achieve a complete resection is the primary treatment, however, if hypothalamic invasion is presented an intended subtotal resection followed by proton beam radiation was shown to have fewer side effects.

Currently, most treatment strategies for these tumors stem from pediatric trials and are translated to adults, due to a paucity of data in the adult cohort. Therefore, and due to the complexity and distinct features of these tumors, interdisciplinary management and discussion with teams specialized in pediatric neurosurgery, pediatric neuro-oncology 
and pediatric neuropathology, on how to diagnose, treat, and follow up these patients is warranted.

Author Contributions: Conceptualization, L.G.; R.G., and J.S.; literature review, L.G. and J.S.; writing-original draft preparation, L.G. writing-review and editing, J.S. and R.G..; visualization, L.G.; supervision, R.G. and J.S..; All authors have read and agreed to the published version of the manuscript.

Funding: This research received no external funding.

Institutional Review Board Statement: Not applicable.

Informed Consent Statement: Not applicable.

Data Availability Statement: Not applicable.

Conflicts of Interest: The authors declare no conflict of interest.

\section{References}

1. Ostrom, Q.T.; Gittleman, H.; Truitt, G.; Boscia, A.; Kruchko, C.; Barnholtz-Sloan, J.S. CBTRUS Statistical Report: Primary Brain and Other Central Nervous System Tumors Diagnosed in the United States in 2011-2015. Neuro-Oncology 2018, 20, iv1-iv86. [CrossRef] [PubMed]

2. Franceschi, E.; Hofer, S.; Brandes, A.A.; Frappaz, D.; Kortmann, R.-D.; Bromberg, J.; Dangouloff-Ros, V.; Boddaert, N.; Hattingen, E.; Wiestler, B.; et al. EANO-EURACAN Clinical Practice Guideline for Diagnosis, Treatment, and Follow-up of Post-Pubertal and Adult Patients with Medulloblastoma. Lancet Oncol 2019, 20, e715-e728. [CrossRef]

3. Schubert, T.; Trippel, M.; Tacke, U.; van Velthoven, V.; Gumpp, V.; Bartelt, S.; Ostertag, C.; Nikkhah, G. Neurosurgical Treatment Strategies in Childhood Craniopharyngiomas: Is Less More? Child's Nerv Syst 2009, 25, 1419. [CrossRef] [PubMed]

4. Calaminus, G.; Frappaz, D.; Kortmann, R.D.; Krefeld, B.; Saran, F.; Pietsch, T.; Vasiljevic, A.; Garre, M.L.; Ricardi, U.; Mann, J.R.; et al. Outcome of Patients with Intracranial Non-Germinomatous Germ Cell Tumors-Lessons from the SIOP-CNS-GCT-96 Trial. Neuro-oncology 2017, 19, 1661-1672. [CrossRef] [PubMed]

5. Tabash, M.A. Characteristics, Survival and Incidence Rates and Trends of Pilocytic Astrocytoma in Children in the United States; SEER-Based Analysis. J. Neurol. Sci. 2019, 400, 148-152. [CrossRef] [PubMed]

6. Johnson, D.R.; Brown, P.D.; Galanis, E.; Hammack, J.E. Pilocytic Astrocytoma Survival in Adults: Analysis of the Surveillance, Epidemiology, and End Results Program of the National Cancer Institute. J. Neuro-Oncol. 2012, 108, 187-193. [CrossRef] [PubMed]

7. Juraschka, K.; Taylor, M.D. Medulloblastoma in the Age of Molecular Subgroups: A Review: JNSPG 75th Anniversary Invited Review Article. J. Neurosurg. Pediatr. 2019, 24, 353-363. [CrossRef]

8. Carta, R.; Del Baldo, G.; Miele, E.; Po, A.; Besharat, Z.M.; Nazio, F.; Colafati, G.S.; Piccirilli, E.; Agolini, E.; Rinelli, M.; et al. Cancer Predisposition Syndromes and Medulloblastoma in the Molecular Era. Front. Oncol. 2020, 10, 566822. [CrossRef] [PubMed]

9. Hill, R.M.; Richardson, S.; Schwalbe, E.C.; Hicks, D.; Lindsey, J.C.; Crosier, S.; Rafiee, G.; Grabovska, Y.; Wharton, S.B.; Jacques, T.S.; et al. Time, Pattern, and Outcome of Medulloblastoma Relapse and Their Association with Tumour Biology at Diagnosis and Therapy: A Multicentre Cohort Study. Lancet Child Adolesc. Health 2020, 4, 865-874. [CrossRef]

10. Chang, C.H.; Housepian, E.M.; Herbert, C. An Operative Staging System and a Megavoltage Radiotherapeutic Technic for Cerebellar Medulloblastomas. Radiology 1969, 93, 1351-1359. [CrossRef] [PubMed]

11. Padovani, L.; Sunyach, M.-P.; Perol, D.; Mercier, C.; Alapetite, C.; Haie-Meder, C.; Hoffstetter, S.; Muracciole, X.; Kerr, C.; Wagner, J.-P.; et al. Common Strategy for Adult and Pediatric Medulloblastoma: A Multicenter Series of 253 Adults. Int. J. Radiat. Oncol. Biol. Phys. 2007, 68, 433-440. [CrossRef]

12. Brandes, A.A.; Franceschi, E.; Tosoni, A.; Blatt, V.; Ermani, M. Long-term Results of a Prospective Study on the Treatment of Medulloblastoma in Adults. Cancer 2007, 110, 2035-2041. [CrossRef]

13. Louis, D.N.; Perry, A.; Reifenberger, G.; von Deimling, A.; Figarella-Branger, D.; Cavenee, W.K.; Ohgaki, H.; Wiestler, O.D.; Kleihues, P.; Ellison, D.W. The 2016 World Health Organization Classification of Tumors of the Central Nervous System: A Summary. Acta Neuropathol. 2016, 131, 803-820. [CrossRef]

14. Giangaspero, F.; Perilongo, G.; Fondelli, M.P.; Brisigotti, M.; Carollo, C.; Burnelli, R.; Burger, P.C.; Garrè, M.L. Medulloblastoma with Extensive Nodularity: A Variant with Favorable Prognosis. J.Neurosurg. 1999, 91, 971-977. [CrossRef] [PubMed]

15. Orr, B.A. Pathology, Diagnostics, and Classification of Medulloblastoma. Brain Pathol. 2020, 30, 664-678. [CrossRef] [PubMed]

16. Louis, D.N.; Ohgaki, H.; Wiestler, O.D.; Cavenee, W.K.; Burger, P.C.; Jouvet, A.; Scheithauer, B.W.; Kleihues, P. The 2007 WHO Classification of Tumours of the Central Nervous System. Acta Neuropathol. 2007, 114, 97-109. [CrossRef]

17. Capozza, M.A.; Trombatore, G.; Triarico, S.; Mastrangelo, S.; Attinà, G.; Maurizi, P.; Ruggiero, A. Adult Medulloblastoma: An Overview on Current and Future Strategies of Treatment. Expert Opin. Orphan D 2019, 7, 1-7. [CrossRef]

18. Ramaswamy, V.; Remke, M.; Bouffet, E.; Bailey, S.; Clifford, S.C.; Doz, F.; Kool, M.; Dufour, C.; Vassal, G.; Milde, T.; et al. Risk Stratification of Childhood Medulloblastoma in the Molecular Era: The Current Consensus. Acta Neuropathol. 2016, 131, 821-831. [CrossRef] [PubMed] 
19. Sharma, T.; Schwalbe, E.C.; Williamson, D.; Sill, M.; Hovestadt, V.; Mynarek, M.; Rutkowski, S.; Robinson, G.W.; Gajjar, A.; Cavalli, F.; et al. Second-Generation Molecular Subgrouping of Medulloblastoma: An International Meta-Analysis of Group 3 and Group 4 Subtypes. Acta Neuropathol. 2019, 138, 309-326. [CrossRef] [PubMed]

20. D'Arcy, C.E.; Nobre, L.F.; Arnaldo, A.; Ramaswamy, V.; Taylor, M.D.; Naz-Hazrati, L.; Hawkins, C.E. Immunohistochemical and NanoString-Based Subgrouping of Clinical Medulloblastoma Samples. J Neuropathol. Exp. Neurol. 2020, 79, 437-447. [CrossRef]

21. Ellison, D.W.; Dalton, J.; Kocak, M.; Nicholson, S.L.; Fraga, C.; Neale, G.; Kenney, A.M.; Brat, D.J.; Perry, A.; Yong, W.H.; et al. Medulloblastoma: Clinicopathological Correlates of SHH, WNT, and Non-SHH/WNT Molecular Subgroups. Acta Neuropathol. 2011, 121, 381-396. [CrossRef] [PubMed]

22. Zhao, F.; Ohgaki, H.; Xu, L.; Giangaspero, F.; Li, C.; Li, P.; Yang, Z.; Wang, B.; Wang, X.; Wang, Z.; et al. Molecular Subgroups of Adult Medulloblastoma: A Long-Term Single-Institution Study. Neuro-Oncology 2016, 18. [CrossRef]

23. Remke, M.; Hielscher, T.; Northcott, P.A.; Witt, H.; Ryzhova, M.; Wittmann, A.; Benner, A.; von Deimling, A.; Scheurlen, W.; Perry, A.; et al. Adult Medulloblastoma Comprises Three Major Molecular Variants. J. Clin. Oncol. 2011, 29, 2717-2723. [CrossRef] [PubMed]

24. Wong, G.C.-H.; Li, K.K.-W.; Wang, W.-W.; Liu, A.P.-Y.; Huang, Q.J.; Chan, A.K.-Y.; Poon, M.F.-M.; Chung, N.Y.-F.; Wong, Q.H.-W.; Chen, H.; et al. Clinical and Mutational Profiles of Adult Medulloblastoma Groups. Acta Neuropathol. Commun. $2020,8,191$. [CrossRef] [PubMed]

25. Kool, M.; Korshunov, A.; Pfister, S.M. Update on Molecular and Genetic Alterations in Adult Medulloblastoma. MEMO Mag. Eur. Med. Oncol. 2012, 5, 228-232. [CrossRef] [PubMed]

26. Northcott, P.A.; Korshunov, A.; Witt, H.; Hielscher, T.; Eberhart, C.G.; Mack, S.; Bouffet, E.; Clifford, S.C.; Hawkins, C.E.; French, P.; et al. Medulloblastoma Comprises Four Distinct Molecular Variants. J. Clin. Oncol. 2010, 29, 1408-1414. [CrossRef] [PubMed]

27. Franceschi, E.; Minichillo, S.; Mura, A.; Tosoni, A.; Mascarin, M.; Tomasello, C.; Bartolini, S.; Brandes, A.A. Adjuvant Chemotherapy in Average-Risk Adult Medulloblastoma Patients Improves Survival: A Long Term Study. BMC Cancer 2020, $20,755$. [CrossRef] [PubMed]

28. von Bueren, A.O.; Friedrich, C.; von Hoff, K.; Kwiecien, R.; Müller, K.; Pietsch, T.; Warmuth-Metz, M.; Hau, P.; Benesch, M.; Kuehl, J.; et al. Metastatic Medulloblastoma in Adults: Outcome of Patients Treated According to the HIT2000 Protocol. Eur. J. Cancer 2015, 51, 2434-2443. [CrossRef] [PubMed]

29. Tabori, U.; Sung, L.; Hukin, J.; Laperriere, N.; Crooks, B.; Carret, A.-S.; Silva, M.; Odame, I.; Mpofu, C.; Strother, D.; et al. Medulloblastoma in the Second Decade of Life: A Specific Group with Respect to Toxicity and Management. Cancer 2005, 103, 1874-1880. [CrossRef] [PubMed]

30. Li, Y.; Song, Q.; Day, B.W. Phase I and Phase II Sonidegib and Vismodegib Clinical Trials for the Treatment of Paediatric and Adult MB Patients: A Systemic Review and Meta-Analysis. Acta Neuropathol. Commun. 2019, 7, 123. [CrossRef]

31. Packer, R.J.; Sutton, L.N.; Goldwein, J.W.; Perilongo, G.; Bunin, G.; Ryan, J.; Cohen, B.H.; D’Angio, G.; Kramer, E.D.; Zimmerman, R.A.; et al. Improved Survival with the Use of Adjuvant Chemotherapy in the Treatment of Medulloblastoma. J. Neurosurg. 1991, 74, 433-440. [CrossRef] [PubMed]

32. von Bueren, A.O.; von Hoff, K.; Pietsch, T.; Gerber, N.U.; Warmuth-Metz, M.; Deinlein, F.; Zwiener, I.; Faldum, A.; Fleischhack, G.; Benesch, M.; et al. Treatment of Young Children with Localized Medulloblastoma by Chemotherapy Alone: Results of the Prospective, Multicenter Trial HIT 2000 Confirming the Prognostic Impact of Histology. Neuro-Oncology 2011, 13, 669-679. [CrossRef] [PubMed]

33. Ang, C.; Hauerstock, D.; Guiot, M.; Kasymjanova, G.; Roberge, D.; Kavan, P.; Muanza, T. Characteristics and Outcomes of Medulloblastoma in Adults. Pediatr. Blood Cancer 2008, 51, 603-607. [CrossRef] [PubMed]

34. Brasme, J.-F.; Chalumeau, M.; Doz, F.; Lacour, B.; Valteau-Couanet, D.; Gaillard, S.; Delalande, O.; Aghakhani, N.; Sainte-Rose, C.; Puget, S.; et al. Interval between Onset of Symptoms and Diagnosis of Medulloblastoma in Children: Distribution and Determinants in a Population-Based Study. Eur. J. Pediatr. 2012, 171, 25-32. [CrossRef] [PubMed]

35. Kunschner, L.J.; Kuttesch, J.; Hess, K.; Yung, W.K.A. Survival and Recurrence Factors in Adult Medulloblastoma: The M.D. Anderson Cancer Center Experience from 1978 to 1998. Neuro-Oncology 2001, 3, 167-173. [CrossRef] [PubMed]

36. Fattal-Valevski, A.; Nissan, N.; Kramer, U.; Constantini, S. Seizures as the Clinical Presenting Symptom in Children with Brain Tumors. J. Child Neurol. 2012, 28, 292-296. [CrossRef] [PubMed]

37. Majd, N.; Penas-Prado, M. Updates on Management of Adult Medulloblastoma. Curr. Treat. Option Oncol. 2019, 20, 64. [CrossRef]

38. Warren, K.E.; Vezina, G.; Poussaint, T.Y.; Warmuth-Metz, M.; Chamberlain, M.C.; Packer, R.J.; Brandes, A.A.; Reiss, M.; Goldman, S.; Fisher, M.J.; et al. Response Assessment in Medulloblastoma and Leptomeningeal Seeding Tumors: Recommendations from the Response Assessment in Pediatric Neuro-Oncology Committee. Neuro-Oncology 2017, 20, 13-23. [CrossRef] [PubMed]

39. Schneider, C.; Ramaswamy, V.; Kulkarni, A.V.; Rutka, J.T.; Remke, M.; Tabori, U.; Hawkins, C.; Bouffet, E.; Taylor, M.D. Clinical Implications of Medulloblastoma Subgroups: Incidence of CSF Diversion Surgery. J. Neurosurg. Pediatr. 2015, 15, $236-242$. [CrossRef] [PubMed]

40. Mangubat, E.Z.; Chan, M.; Ruland, S.; Roitberg, B.Z. Hydrocephalus in Posterior Fossa Lesions: Ventriculostomy and Permanent Shunt Rates by Diagnosis. Neurol. Res. 2009, 31, 668-673. [CrossRef]

41. Won, S.-Y.; Dubinski, D.; Behmanesh, B.; Bernstock, J.D.; Seifert, V.; Konczalla, J.; Tritt, S.; Senft, C.; Gessler, F. Management of Hydrocephalus after Resection of Posterior Fossa Lesions in Pediatric and Adult Patients_Predictors for Development of Hydrocephalus. Neurosurg. Rev. 2020, 43, 1143-1150. [CrossRef] 
42. Riva-Cambrin, J.; Detsky, A.S.; Lamberti-Pasculli, M.; Sargent, M.A.; Armstrong, D.; Moineddin, R.; Cochrane, D.D.; Drake, J.M. Predicting Postresection Hydrocephalus in Pediatric Patients with Posterior Fossa Tumors. J. Neurosurg. Pediatr. PED 2009, 3, 378-385. [CrossRef] [PubMed]

43. Thompson, E.M.; Hielscher, T.; Bouffet, E.; Remke, M.; Luu, B.; Gururangan, S.; McLendon, R.E.; Bigner, D.D.; Lipp, E.S.; Perreault, S.; et al. Prognostic Value of Medulloblastoma Extent of Resection after Accounting for Molecular Subgroup: A Retrospective Integrated Clinical and Molecular Analysis. Lancet Oncol. 2016, 17, 484-495. [CrossRef]

44. Wibroe, M.; Rochat, P.; Juhler, M. Cerebellar Mutism Syndrome and Other Complications After Surgery in the Posterior Fossa in Adults: A Prospective Study. World Neurosurg. 2018, 110, e738-e746. [CrossRef] [PubMed]

45. Schmahmann, J.D. Pediatric Post-Operative Cerebellar Mutism Syndrome, Cerebellar Cognitive Affective Syndrome, and Posterior Fossa Syndrome: Historical Review and Proposed Resolution to Guide Future Study. Childs Nerv. Syst. 2020, 36, 1205-1214. [CrossRef]

46. Buglione, M.; Ghirardelli, P.; Triggiani, L.; Pedretti, S.; Pasinetti, N.; De Bari, B.; Tonoli, S.; Borghetti, P.; Spiazzi, L.; Magrini, S.M. Radiotherapy for Adult Medulloblastoma: Long Term Result from a Single Institution. A Review of Prognostic Factors and Why We Do Need a Multi-Institutional Cooperative Program. Rep. Pract. Oncol. Radiother. 2015, 20, 284-291. [CrossRef]

47. Friedrich, C. Treatment of Adult Nonmetastatic Medulloblastoma Patients According to the Paediatric HIT 2000 Protocol: A Prospective Observational Multicentre Study. Eur. J. Cancer 2013, 49, 893-903. [CrossRef] [PubMed]

48. MacDonald, T.J.; Aguilera, D.; Castellino, R.C. The Rationale for Targeted Therapies in Medulloblastoma. Neuro-Oncology 2014, 16, 9-20. [CrossRef] [PubMed]

49. Wang, J.; Garancher, A.; Ramaswamy, V.; Wechsler-Reya, R.J. Medulloblastoma: From Molecular Subgroups to Molecular Targeted Therapies. Annu. Rev. Neurosci. 2015, 41,1-26. [CrossRef]

50. Kieran, M.W.; Chisholm, J.; Casanova, M.; Brandes, A.A.; Aerts, I.; Bouffet, E.; Bailey, S.; Leary, S.; MacDonald, T.J.; Mechinaud, F.; et al. Phase I Study of Oral Sonidegib (LDE225) in Pediatric Brain and Solid Tumors and a Phase II Study in Children and Adults with Relapsed Medulloblastoma. Neuro-Oncology 2017, 19, 1542-1552. [CrossRef]

51. Robinson, G.W.; Orr, B.A.; Wu, G.; Gururangan, S.; Lin, T.; Qaddoumi, I.; Packer, R.J.; Goldman, S.; Prados, M.D.; Desjardins, A.; et al. Vismodegib Exerts Targeted Efficacy Against Recurrent Sonic Hedgehog-Subgroup Medulloblastoma: Results From Phase II Pediatric Brain Tumor Consortium Studies PBTC-025B and PBTC-032. JCO 2015, 33, 2646-2654. [CrossRef] [PubMed]

52. Segal, D.; Karajannis, M.A. Pediatric Brain Tumors: An Update. Curr. Probl. Pediatr. Adolesc. Health Care 2016, 46, 242-250. [CrossRef] [PubMed]

53. Lobbous, M.; Bernstock, J.D.; Coffee, E.; Friedman, G.K.; Metrock, L.K.; Chagoya, G.; Elsayed, G.; Nakano, I.; Hackney, J.R.; Korf, B.R.; et al. An Update on Neurofibromatosis Type 1-Associated Gliomas. Cancers 2020, 12, 114. [CrossRef] [PubMed]

54. D'Angelo, F.; Ceccarelli, M.; Tala; Garofano, L.; Zhang, J.; Frattini, V.; Caruso, F.P.; Lewis, G.; Alfaro, K.D.; Bauchet, L.; et al. The Molecular Landscape of Glioma in Patients with Neurofibromatosis 1. Nat. Med. 2019, 25, 176-187. [CrossRef]

55. Burkhard, C.; Patre, P.-L.D.; Schüler, D.; Schüler, G.; Yaşargil, M.G.; Yonekawa, Y.; Lütolf, U.M.; Kleihues, P.; Ohgaki, H. A Population-Based Study of the Incidence and Survival Rates in Patients with Pilocytic Astrocytoma. J. Neurosurg. 2003, 98, 1170-1174. [CrossRef] [PubMed]

56. Theeler, B.J.; Ellezam, B.; Sadighi, Z.S.; Mehta, V.; Tran, M.D.; Adesina, A.M.; Bruner, J.M.; Puduvalli, V.K. Adult Pilocytic Astrocytomas: Clinical Features and Molecular Analysis. Neuro-Oncology 2014, 16, 841-847. [CrossRef]

57. Salles, D.; Laviola, G. Pilocytic Astrocytoma: A Review of General, Clinical, and Molecular Characteristics. J. Child Neurol. 2020, 35, 852-858. [CrossRef] [PubMed]

58. Soleman, J.; Kozyrev, D.A.; Ben-Sira, L.; Constantini, S.; Roth, J. Management of Incidental Brain Tumors in Children: A Systematic Review. Childs Nerv. Syst. 2020, 36, 1607-1619. [CrossRef]

59. Soleman, J.; Roth, J.; Ram, Z.; Yalon, M.; Constantini, S. Malignant Transformation of a Conservatively Managed Incidental Childhood Cerebral Mass Lesion: Controversy Regarding Management Paradigm. Childs Nerv. Syst. 2017, 33, 2169-2175. [CrossRef]

60. Collins, V.P.; Jones, D.T.W.; Giannini, C. Pilocytic Astrocytoma: Pathology, Molecular Mechanisms and Markers. Acta Neuropathol. 2015, 129, 775-788. [CrossRef]

61. Rodriguez, F.J.; Scheithauer, B.W.; Burger, P.C.; Jenkins, S.; Giannini, C. Anaplasia in Pilocytic Astrocytoma Predicts Aggressive Behavior. Am. J. Surg. Pathol. 2010, 34, 147-160. [CrossRef] [PubMed]

62. Reinhardt, A.; Stichel, D.; Schrimpf, D.; Sahm, F.; Korshunov, A.; Reuss, D.E.; Koelsche, C.; Huang, K.; Wefers, A.K.; Hovestadt, V.; et al. Anaplastic Astrocytoma with Piloid Features, a Novel Molecular Class of IDH Wildtype Glioma with Recurrent MAPK Pathway, CDKN2A/B and ATRX Alterations. Acta Neuropathol. 2018, 136, 273-291. [CrossRef] [PubMed]

63. Jones, D.T.W.; Kocialkowski, S.; Liu, L.; Pearson, D.M.; Bäcklund, L.M.; Ichimura, K.; Collins, V.P. Tandem Duplication Producing a Novel Oncogenic BRAF Fusion Gene Defines the Majority of Pilocytic Astrocytomas. Cancer Res. 2008, 68, 8673-8677. [CrossRef] [PubMed]

64. Horbinski, C. To BRAF or Not to BRAF: Is That Even a Question Anymore? J. Neuropathol. Exp. Neurol. 2013, 72, 2-7. [CrossRef]

65. Pollack, I.F.; Agnihotri, S.; Broniscer, A. Childhood Brain Tumors: Current Management, Biological Insights, and Future Directions: JNSPG 75th Anniversary Invited Review Article. J. Neurosurg. Pediatr. 2019, 23, 261-273. [CrossRef] 
66. Pathak, P.; Kumar, A.; Jha, P.; Purkait, S.; Faruq, M.; Suri, A.; Suri, V.; Sharma, M.C.; Sarkar, C. Genetic Alterations Related to BRAF-FGFR Genes and Dysregulated MAPK/ERK/MTOR Signaling in Adult Pilocytic Astrocytoma. Brain Pathol. 2017, 27, 580-589. [CrossRef]

67. Kristiansen, I.; Strinnholm, M.; Strömberg, B.; Frisk, P. Clinical Characteristics, Long-Term Complications and Health-Related Quality of Life (HRQoL) in Children and Young Adults Treated for Low-Grade Astrocytoma in the Posterior Fossa in Childhood. J. Neuro-Oncol. 2019, 142, 203-210. [CrossRef] [PubMed]

68. Horger, M.; Beschorner, R.; Nägele, T.; Danz, S.; Ernemann, U. Pilozytisches Astrozytom: Bildgebende Diagnostik. Röfo Fortschritte Auf Dem Gebiet Der Röntgenstrahlen Und Der Bildgebenden Verfahren 2009, 181, 1109-1112. [CrossRef] [PubMed]

69. She, D.; Lu, Y.; Xiong, J.; Geng, D.; Yin, B. MR Imaging Features of Spinal Pilocytic Astrocytoma. BMC Med. Imaging 2019, 19, 5. [CrossRef] [PubMed]

70. Lee, K.J.; Marchan, E.; Peterson, J.; Harrell, A.C.; Quinones-Hinojosa, A.; Brown, P.D.; Trifiletti, D.M. Management and Survival of Adult Patients with Pilocytic Astrocytoma in the National Cancer Database. World Neurosurg. 2018, 112, e881-e887. [CrossRef] [PubMed]

71. Beni-Adani, L.; Gomori, M.; Spektor, S.; Constantini, S. Cyst Wall Enhancement in Pilocytic Astrocytoma: Neoplastic or Reactive Phenomena. Pediatr. Neurosurg. 2000, 32, 234-239. [CrossRef]

72. Wade, A.; Hayhurst, C.; Amato-Watkins, A.; Lammie, A.; Leach, P. Cerebellar Pilocytic Astrocytoma in Adults: A Management Paradigm for a Rare Tumour. Acta Neurochir. 2013, 155, 1431-1435. [CrossRef] [PubMed]

73. Stüer, C.; Vilz, B.; Majores, M.; Becker, A.; Schramm, J.; Simon, M. Frequent Recurrence and Progression in Pilocytic Astrocytoma in Adults. Cancer 2007, 110, 2799-2808. [CrossRef] [PubMed]

74. Kano, H.; Kondziolka, D.; Niranjan, A.; Flickinger, J.C.; Lunsford, L.D. Stereotactic Radiosurgery for Pilocytic Astrocytomas Part 1: Outcomes in Adult Patients. J. Neuro-Oncol. 2009, 95, 211-218. [CrossRef]

75. Parsons, M.W.; Whipple, N.S.; Poppe, M.M.; Mendez, J.S.; Cannon, D.M.; Burt, L.M. The Use and Efficacy of Chemotherapy and Radiotherapy in Children and Adults with Pilocytic Astrocytoma. J. Neuro-Oncol. 2021, 151, 93-101. [CrossRef] [PubMed]

76. Lassaletta, A.; Scheinemann, K.; Zelcer, S.M.; Hukin, J.; Wilson, B.A.; Jabado, N.; Carret, A.S.; Lafay-Cousin, L.; Larouche, V.; Hawkins, C.E.; et al. Phase II Weekly Vinblastine for Chemotherapy-Naïve Children With Progressive Low-Grade Glioma: A Canadian Pediatric Brain Tumor Consortium Study. J. Clin. Oncol. 2016, 34, 3537-3543. [CrossRef] [PubMed]

77. Schreck, K.C.; Grossman, S.A.; Pratilas, C.A. BRAF Mutations and the Utility of RAF and MEK Inhibitors in Primary Brain Tumors. Cancers 2019, 11, 1262. [CrossRef] [PubMed]

78. Fangusaro, J.; Onar-Thomas, A.; Poussaint, T.Y.; Wu, S.; Ligon, A.H.; Lindeman, N.; Banerjee, A.; Packer, R.J.; Kilburn, L.B.; Goldman, S.; et al. Selumetinib in Paediatric Patients with BRAF-Aberrant or Neurofibromatosis Type 1-Associated Recurrent, Refractory, or Progressive Low-Grade Glioma: A Multicentre, Phase 2 Trial. Lancet Oncol. 2019, 20, 1011-1022. [CrossRef]

79. Bunin, G.R.; Surawicz, T.S.; Witman, P.A.; Preston-Martin, S.; Davis, D.F.; Bruner, J.M. The Descriptive Epidemiology of Craniopharyngioma. J. Neurosurg. 1998, 89, 547-551. [CrossRef]

80. Momin, A.A.; Recinos, M.A.; Cioffi, G.; Patil, N.; Soni, P.; Almeida, J.P.; Kruchko, C.; Barnholtz-Sloan, J.S.; Recinos, P.F.; Kshettry, V.R. Descriptive Epidemiology of Craniopharyngiomas in the United States. Pituitary 2021. [CrossRef] [PubMed]

81. Nielsen, E.H.; Feldt-Rasmussen, U.; Poulsgaard, L.; Kristensen, L.Ø.; Astrup, J.; Jørgensen, J.O.; Bjerre, P.; Andersen, M.; Andersen, C.; Jørgensen, J.; et al. Incidence of Craniopharyngioma in Denmark $(\mathrm{n}=189)$ and Estimated World Incidence of Craniopharyngioma in Children and Adults. J. Neuro-Oncol. 2011, 104, 755-763. [CrossRef]

82. Jouanneau, E.; Raverot, G. Adult Craniopharyngiomas, Differences and Lessons from Paediatrics; Springer: Cham, Switzerland, 2020. [CrossRef]

83. Lubuulwa, J.; Lei, T. Pathological and Topographical Classification of Craniopharyngiomas: A Literature Review. J. Neurol. Surg. Rep. 2016, 77, e121-e127. [CrossRef]

84. Karavitaki, N.; Brufani, C.; Warner, J.T.; Adams, C.B.T.; Richards, P.; Ansorge, O.; Shine, B.; Turner, H.E.; Wass, J.A.H. Craniopharyngiomas in Children and Adults: Systematic Analysis of 121 Cases with Long-term Follow-up. Clin. Endocrinol. 2005, 62, 397-409. [CrossRef] [PubMed]

85. Müller, H.L. Craniopharyngioma. Endocr. Rev. 2014, 35, 513-543. [CrossRef] [PubMed]

86. Brastianos, P.K.; Taylor-Weiner, A.; Manley, P.E.; Jones, R.T.; Dias-Santagata, D.; Thorner, A.R.; Lawrence, M.S.; Rodriguez, F.J.; Bernardo, L.A.; Schubert, L.; et al. Exome Sequencing Identifies BRAF Mutations in Papillary Craniopharyngiomas. Nat. Genet. 2014, 46, 161-165. [CrossRef]

87. Kirollos, R.W.; Helmy, A.; Thomson, S.; Hutchinson, P.J. Oxford Textbook of Neurological Surgery, 1st ed.; Oxford University Press: Oxford, UK, 2019; ISBN 978-0-19-874670-6.

88. Hölsken, A.; Sill, M.; Merkle, J.; Schweizer, L.; Buchfelder, M.; Flitsch, J.; Fahlbusch, R.; Metzler, M.; Kool, M.; Pfister, S.M.; et al. Adamantinomatous and Papillary Craniopharyngiomas Are Characterized by Distinct Epigenomic as Well as Mutational and Transcriptomic Profiles. Acta Neuropathol. Commun. 2016, 4, 20. [CrossRef] [PubMed]

89. Puget, S.; Grill, J.; Zerah, M.; Pierre-Kahn, A. Pediatric Craniopharyngiomas: Classification and Treatment According to the Degree of Hypothalamic Involvement. J. Neurosurg. 2007, 106, 10. [CrossRef]

90. Lopez-Serna, R.; Gómez-Amador, J.L.; Barges-Coll, J.; Nathal-Vera, E.; Revuelta-Gutiérrez, R.; Alonso-Vanegas, M.; Ramos-Peek, M.; Portocarrero-Ortiz, L. Treatment of Craniopharyngioma in Adults: Systematic Analysis of a 25-Year Experience. Arch. Med. Res. 2012, 43, 347-355. [CrossRef] [PubMed] 
91. Jensterle, M.; Jazbinsek, S.; Bosnjak, R.; Popovic, M.; Zaletel, L.Z.; Vesnaver, T.V.; Kotnik, B.F.; Kotnik, P. Advances in the Management of Craniopharyngioma in Children and Adults. Radiol. Oncol. 2019, 53, 388-396. [CrossRef]

92. Jazbinšek, S.; Kolenc, D.; Bošnjak, R.; Faganel Kotnik, B.; Zadravec Zaletel, L.; Jenko Bizjan, B.; Vipotnik Vesnaver, T.; Battelino, T.; Janež, A.; Jensterle, M.; et al. Prevalence of Endocrine and Metabolic Comorbidities in a National Cohort of Patients with Craniopharyngioma. Horm. Res. Paediatr. 2020, 93, 46-57. [CrossRef] [PubMed]

93. Müller, H.L. Childhood Craniopharyngioma. Pituitary 2013, 16, 56-67. [CrossRef] [PubMed]

94. Müller, H.L.; Bruhnken, G.; Emser, A.; Faldum, A.; Etavard-Gorris, N.; Gebhardt, U.; Kolb, R.; Sörensen, N. Longitudinal Study on Quality of Life in 102 Survivors of Childhood Craniopharyngioma. Child's Nerv. Syst. 2005, 21, 975-980. [CrossRef] [PubMed]

95. Bogusz, A.; Boekhoff, S.; Warmuth-Metz, M.; Calaminus, G.; Eveslage, M.; Müller, H.L. Posterior Hypothalamus-Sparing Surgery Improves Outcome after Childhood Craniopharyngioma. Endocr. Connect. 2019, 8, 481-492. [CrossRef] [PubMed]

96. Jung, T.-Y.; Jung, S.; Moon, K.-S.; Kim, I.-Y.; Kang, S.-S.; Kim, J.-H. Endocrinological Outcomes of Pediatric Craniopharyngiomas with Anatomical Pituitary Stalk Preservation: Preliminary Study. Pediatr. Neurosurg. 2010, 46, 205-212. [CrossRef] [PubMed]

97. Cheng, J.; Fan, Y.; Cen, B. Effect of Preserving the Pituitary Stalk During Resection of Craniopharyngioma in Children on the Diabetes Insipidus and Relapse Rates and Long-Term Outcomes. J. Craniofac. Surg. 2017, 28, e591-e595. [CrossRef] [PubMed]

98. Li, K.; Lu, X.; Yang, N.; Zheng, J.; Huang, B.; Li, L. Association of Pituitary Stalk Management with Endocrine Outcomes and Recurrence in Microsurgery of Craniopharyngiomas: A Meta-Analysis. Clin. Neurol. Neurosur. 2015, 136, 20-24. [CrossRef]

99. Albright, A.L.; Hadjipanayis, C.G.; Lunsford, L.D.; Kondziolka, D.; Pollack, I.F.; Adelson, P.D. Individualized Treatment of Pediatric Craniopharyngiomas. Child's Nerv. Syst. 2005, 21, 649-654. [CrossRef] [PubMed]

100. MG, Y.; M, C.; M, K.; G, S.; PJ, T.; P, R. Total Removal of Craniopharyngiomas. Approaches and Long-Term Results in 144 Patients. J. Neurosurg. 1990, 73, 3-11.

101. Fouda, M.A.; Karsten, M.; Staffa, S.J.; Scott, R.M.; Marcus, K.J.; Baird, L.C. Management Strategies for Recurrent Pediatric Craniopharyngioma: New Recommendations. J. Neurosurg. Pediatr. 2021, 1-8. [CrossRef]

102. Effenterre, R.V.; Boch, A.-L. Craniopharyngioma in Adults and Children: A Study of 122 Surgical Cases. J. Neurosurg. 2002, 97, 3-11. [CrossRef]

103. Ajithkumar, T.; Mazhari, A.-L.; Stickan-Verfürth, M.; Kramer, P.-H.; Fuentes, C.-S.; Lambert, J.; Thomas, H.; Müller, H.; Fleischhack, G.; Timmermann, B. Proton Therapy for Craniopharyngioma-An Early Report from a Single European Centre. Clin. Oncol. 2018, 30, 307-316. [CrossRef]

104. Patel, V.S.; Thamboo, A.; Quon, J.; Nayak, J.V.; Hwang, P.H.; Edwards, M.; Patel, Z.M. Outcomes After Endoscopic Endonasal Resection of Craniopharyngiomas in the Pediatric Population. World Neurosurg 2017, 108, 6-14. [CrossRef] [PubMed]

105. Tatreau, J.R.; Patel, M.R.; Shah, R.N.; McKinney, K.A.; Wheless, S.A.; Senior, B.A.; Ewend, M.G.; Germanwala, A.V.; Ebert, C.S.; Zanation, A.M. Anatomical Considerations for Endoscopic Endonasal Skull Base Surgery in Pediatric Patients. Laryngoscope 2010, 120, 1730-1737. [CrossRef] [PubMed]

106. Komotar, R.J.; Starke, R.M.; Raper, D.M.S.; Anand, V.K.; Schwartz, T.H. Endoscopic Endonasal Compared with Microscopic Transsphenoidal and Open Transcranial Resection of Craniopharyngiomas. World Neurosurg. 2012, 77, 329-341. [CrossRef]

107. Fahlbusch, R.; Honegger, J.; Paulus, W.; Huk, W.; Buchfelder, M. Surgical Treatment of Craniopharyngiomas: Experience with 168 Patients. J. Neurosurg. 1999, 90, 237-250. [CrossRef] [PubMed]

108. Zoicas, F.; Schöfl, C. Craniopharyngioma in Adults. Front. Endocrinol. 2012, 3, 46. [CrossRef] [PubMed]

109. Boehling, N.S.; Grosshans, D.R.; Bluett, J.B.; Palmer, M.T.; Song, X.; Amos, R.A.; Sahoo, N.; Meyer, J.J.; Mahajan, A.; Woo, S.Y. Dosimetric Comparison of Three-Dimensional Conformal Proton Radiotherapy, Intensity-Modulated Proton Therapy, and Intensity-Modulated Radiotherapy for Treatment of Pediatric Craniopharyngiomas. Int. J. Radiation Oncol. Biol. Phys. 2012, 82, 643-652. [CrossRef]

110. Müller, H.L. The Diagnosis and Treatment of Craniopharyngioma. Neuroendocrinology 2020, 110, 753-766. [CrossRef] [PubMed]

111. Gupta, S.; Bi, W.L.; Giantini Larsen, A.; Al-Abdulmohsen, S.; Abedalthagafi, M.; Dunn, I.F. Craniopharyngioma: A Roadmap for Scientific Translation. Neurosurg. Focus 2018, 44, E12. [CrossRef]

112. Patel, K.; Allen, J.; Zagzag, D.; Wisoff, J.; Radmanesh, A.; Gindin, T.; Nicolaides, T. Radiologic Response to MEK Inhibition in a Patient with a WNT-activated Craniopharyngioma. Pediatr. Blood Cancer 2021, 68. [CrossRef] [PubMed]

113. Hengartner, A.C.; Prince, E.; Vijmasi, T.; Hankinson, T.C. Adamantinomatous Craniopharyngioma: Moving toward Targeted Therapies. Neurosurg. Focus 2020, 48, E7. [CrossRef] [PubMed] 